\title{
Profile of Worry in the U.S.
}

\author{
Veli Safak'
}

$06 / 23 / 2020$

Objective: To identify most and least common causes of worry for the general population and twenty-eight population groups on eight causes of worries. These worries are medical costs due to illness/accident, medical costs of normal healthcare, maintaining the standard of living, paying rent/mortgage/housing costs, paying monthly bills, credit card payments, paying for children's college, and money for retirement.

Design: $\quad$ Six cross-sectional annual health surveys in the National Health Interview Survey, $2013-2018$.

Setting: $\quad$ General health care, representative population study.

Participants: Men and women, 25-85 years.

Main results: $\quad$ Paying for children's college, money for retirement, and medical costs due to illness/accident are the most common causes of worry.

Women are more worried about all worry items than men.

Hispanics worry less often but more about the worry items than non-Hispanics.

Non-citizens worry less often but more about the worry items than citizens.

The frequency and degree of worry are negatively correlated with educational attainment.

Having health insurance coverage reduces the frequency and degree of worry for all worry items.

Every-day smokers have worried feeling more and more often compared to the rest of the population.

Seniors worry less and less often than adults.

Married individuals worry less and less often than singles, widows, separated/divorced individuals, and unmarried couples.

\section{INTRODUCTION}

Borkovec et al. (1983) define worry as a chain of thoughts and images, negatively affect-laden, and relatively uncontrollable. A healthy dose of worry leads us to solve problems and take action. Luana Marques, the president of the Anxiety and Depression Association of America, states ${ }^{2}$ that worry is a way for your brain to handle problems to keep people safe. It's when people get stuck thinking about a problem that worry stops being functional." Excess worry triggers stress hormones ${ }^{3}$ such as cortisol. These hormones boost blood sugar levels and blood fats that fuel the body. However, these hormones may have some adverse effects ${ }^{4}$, such as short-term memory loss, premature coronary artery disease, and heart attack.

Untreated excess worrying can lead to depression and suicidal thoughts. Notably, excessive and uncontrollable worry is the central feature of anxiety disorders. Anxiety occurs when one experiences a lot of worry and stress. According to an Anxiety and Depression Association of America (ADAA) report ${ }^{5}, 40$ million people in the United States (18\%) report an anxiety disorder each year. The same report also states that 1 in every 13 individuals suffer from anxiety around the world. Willis
Tower Watson ${ }^{6}$ polled a global network of 296 insurers in 79 countries in the 2020 Global Medical Survey Report. Between 2011 and 2030, it is estimated that mental health disorders will cost $\$ 16.3$ trillion globally.

Understanding the factor causing population worry is of great economic and public interest. In this paper, I present how eight significant worry sources affect different population groups by using the 2013-2018 data series of the National Health Interview Survey.

\section{DATA AND METHODS}

The data source is a nationally representative cross-sectional survey that collects information about households. The sample consists of 32,206 individuals aged between 25 and 85 . In every calculation, each individual is weighted by using person weight (PERWEIGHT) to represent the general population.

\section{Measures}

Worry Items

For each worry item, listed in Table 1, individuals express the degree of their worries in one of four categories: very worried, moderately worried, not too worried, and not worried at all. In

\footnotetext{
${ }^{1}$ Department of Business Administration, Carnegie Mellon University Qatar, E-mail: vsafak@andrew.cmu.edu

${ }^{2}$ https://www.nytimes.com/2020/02/26/smarter-living/the-difference-between-worry-stress-and-anxiety.html

${ }^{3}$ https://www.webmd.com/balance/guide/how-worrying-affects-your-body\#1

${ }^{4} \mathrm{https} / / /$ www.webmd.com/anxiety-panic/ss/slideshow-worry-body-effects

${ }^{5} \mathrm{https}: / /$ adaa.org/understanding-anxiety

${ }^{6} \mathrm{https} / / /$ www.willistowerswatson.com/en-us/Insights/2019/11/2020-global-medical-trends-survey-report
} 
addition to these items, I also examine how often individuals have worried feelings. The survey measures worry frequency in five categories: daily, weekly, monthly, a few times a year, never.

Table 1. Worry Items

Life
Standard of living
Money for retirement
Paying for children's college
Financial
Paying monthly bills
Paying rent/mortgage/housing costs
Credit card payments
Medical
Medical cost of normal healthcare
Medical cost due to illness/accident
Population groups
I group the sample by using the following sociodemographic
and health-related characteristics.
A. Sociodemographic factors
(1) Gender: female, male
(2) Age: seniors (65 years old or older), and adults (between
25 and 65-year-old)
(3) Educational attainment, categorized in terms of highest
qualification: less than high school, high school, some college,
college, and post-college. The high school category includes
high school and GED. The some college category includes
associate degrees and college dropouts.
(4) Marital status: single, widowed, married, cohabiting and
separated/divorced.
(5) Race: White, African American, Asian American, Native.
(6) Citizenship: Yes, no.
(7) Hispanic: Yes, no.
B. Health behaviors
(1) Smoking status: never smoker, former smoker, someday
smoker, and every-day smoker.
(2) Having health insurance coverage: Yes, no.

\section{Statistical Analysis}

I use tabulations to display the frequency distribution of worry items for each population group.

\section{RESULTS}

\section{Summary Statistics}

Table 2 displays weighted sample means and standard errors of sociodemographic and health-related characteristics.

\section{Smoking}

The association between cigarette smoking and anxiety is a well-documented fact. Cigarette smoke contains chemicals that increase oxidative and nitrosative stress (Stedman 1968).
An increase in plasma markers of oxidative and nitrosative stress is a common feature in animal models of anxiety and anxiety-disordered populations (for review see Hovatta et al. 2010). Smoking also affects neurotransmitter systems and immune system activation, impairs mitochondrial function, and alters neurotrophins, neurogenesis, and methylation of monoamine oxidase promoter genes. These alterations are also observed in cases of anxiety disorders. Furthermore, studies show that smoking cessation is associated with reduced stress, anxiety, and depression (Taylor et al. 2014).

Table 2. Summary Statistics

\begin{tabular}{|c|c|c|}
\hline Variables & $\begin{array}{l}\text { Sample } \\
\text { Fraction }\end{array}$ & $\begin{array}{l}\text { Standard } \\
\text { Error }\end{array}$ \\
\hline Female & .5362 & .4987 \\
\hline Senior & .0509 & .2197 \\
\hline Married & 6199 & .4854 \\
\hline Unmarried Partner & .0693 & .2539 \\
\hline Single & .1217 & .3269 \\
\hline Separated/Divorced & .1650 & .3712 \\
\hline Widowed & .0242 & .1537 \\
\hline White American & .7772 & .4161 \\
\hline African American & .1436 & .3507 \\
\hline Asian American & .0657 & .2477 \\
\hline Native American & .0134 & .115 \\
\hline Less than high school & .1085 & .3110 \\
\hline High school & .2044 & .4033 \\
\hline Some college & .3018 & .4590 \\
\hline College & .2350 & .4240 \\
\hline Post-college & .1502 & .3573 \\
\hline Every-day smoker & .1273 & .3333 \\
\hline Some-day smoker & .0395 & .1948 \\
\hline Former smoker & .1976 & .3982 \\
\hline Never smoker & .6356 & .4812 \\
\hline Citizen $=$ Yes & .8960 & .3053 \\
\hline Insurance $=$ Yes & .8671 & .3395 \\
\hline
\end{tabular}


As Table 3 demonstrates, 19.85 percent of every-day smokers report having worried feelings daily. Meanwhile, only 6.85 percent of never smokers report daily worried feelings. This observation affirms the previous findings (for review, see Moylan et al. 2013). Tables 4-11 show that every-day smokers are more worried than never smokers for all worry items. 41.24 percent of every-day smokers are very worried about paying for their children's college. Also, 37.49 percent of them are very worried about money for retirement, 35 percent of them are very worried about medical costs due to illness/accident, 28.88 percent of them are very worried about maintaining their living standards, 24.88 percent of them are very worried about medical costs for normal healthcare, 24.58 percent of them are very worried about paying bills. These results contribute to the existing literature on the association between cigarette smoking and general anxiety and show that the association between smoking and degree of worrying feelings exists for all eight worry items.

\section{Gender}

Based on a report ${ }^{7}$ by the Anxiety and Depression Association of America (ADAA), women are twice as likely to have an anxiety disorder as men from puberty to the age of 50. This situation is not specific ${ }^{89}$ to the U.S., and there are medical explanations. Men and women are different in terms of brain chemistry and processing serotonin. The CRF is a hormone that organizes stress responses in mammals. The studies suggest that women are more sensitive to low levels of corticotropin-releasing factor (CRF).

Tables 4-11 show that women experience worried feelings more often than men and feel more worried about every worry item. The most considerable difference is observed in worry about financing children's college education. Nearly one in every three women $(30.49 \%)$ and 22.97 percent of men are very worried about paying for children's college. The secondlargest difference is observed for the worry about medical costs due to illness and accidents. One in every four women $(24.87 \%)$ and 18.78 percent of men are very worried about medical costs due to illness and accidents. These findings are aligned with the previous results and explanations in the medical literature (Weissman et al. 2020). Furthermore, they show that women are worried more than men for every common worry item.

\section{Race/Hispanic}

Tables 3-11 show that Asian Americans have lower frequency and degree of worry in all worry items than their African American counterparts. Also, Native Americans report the highest frequency and degree of worry in almost all worry items. Most notably, 32.05 percent of Native Americans are very worried about paying for children's college. In addition,
22.11 percent of Native Americans are very worried about maintaining their living standards, compared to 11.40 percent of Asian Americans. One in four Native Americans are very worried about medical costs due to illness or accident, and one in five Native Americans are very worried about medical costs for normal healthcare. Meanwhile, only one in eleven Asian Americans is very worried about medical costs for normal healthcare.

In addition, African Americans express a high degree of worry in all worry items compared to White Americans. Williams et al. (2012) and Rodriguez et al. (2018) report that African Americans experience more negative anxiety and greater depression than White Americans. Tables 3-11 support their findings. Interestingly, White Americans experience worried feeling more often than African Americans, according to Table 3. These results suggest that African Americans have greater depressions because they have worrying feelings less often but more intensely.

Tables 4-11 indicate the differences between Hispanics and non-Hispanics are similar to those between African and White Americans. Hispanics experience worried feelings less often than non-Hispanics, but they are worried more about all worry items. The most substantial difference is observed in the level of worry about medical costs due to illness/accident. More specifically, 35.60 percent of Hispanics and 19.11 percent of non-Hispanics are very worried about medical costs due to illness/accident. Paying for children's college is the worry item with the second-largest difference between Hispanics and non-Hispanics. Two in every five Hispanics (38.80\%) and one in every four non-Hispanics $(24.46 \%)$ worry about paying for children's college. Finally, the third most significant gap between Hispanics and non-Hispanics is observed for medical costs for normal healthcare. One in every four Hispanics is very worried about medical costs for normal healthcare compared to one in every nine non-Hispanics.

According to a report ${ }^{10}$ by ADAA, the language barrier is an important barrier to treatment among the Hispanic community as many medical professionals do not speak Spanish. Also, the lack of health insurance and legal status are other barriers for Hispanics. These barriers can aggravate the degree of worry and may explain the substantial difference between Hispanics and non-Hispanics. Furthermore, the difference in the degree of worry may also be caused by the lack of information about the cost of healthcare. The disadvantages that Hispanics face can be reduced by providing affordable and accessible mental health care services.

\section{Citizenship}

As Table 3 demonstrates, citizens worry more often than noncitizens. This result is consistent with the immigrant paradox

\footnotetext{
${ }^{7}$ https://adaa.org/living-with-anxiety/women/facts

${ }^{8} \mathrm{https} / / / \mathrm{www} . \mathrm{mentalhealth.org.uk/statistics/mental-health-statistics-men-and-women}$

${ }^{9} \mathrm{https}$ ///www.nhs.uk/news/mental-health/women-are-more-likely-to-suffer-from-anxiety-than-men/

${ }^{10} \mathrm{https} / / /$ adaa.org/hispanic-latinos
} 
(Blue L and Fenelon A 2011). Immigrants tend to exhibit better health outcome even though they arrive from countries with poorer health outcomes (Turner and Gill 2002, Singh et al. 2013)

On the other hand, non-citizens experience a higher degree of worry for all worry items. Notably, two in every five (38.70\%) non-citizens are very worried about medical expenses due to illness/accident relative to one in every five $(20.11 \%)$ citizens. Secondly, 12.64 percent of citizens and 27.22 percent of noncitizens are very worried about medical expenses due to normal healthcare. These findings on medical costs identify non-citizens as a group at-risk to access affordable healthcare.

Non-citizens are also more worried about paying for housing (20.57\%) compared to citizens $(9.48 \%)$. The most important item for both citizens $(25.55 \%)$ and non-citizens $(39.56 \%)$ is paying for children's college. When evaluated in the context of the immigrant paradox, these figures make it more paradoxical. Although non-citizens are more worried, they have worried feelings less often than citizens.

\section{Education}

Many studies associate education with improved mental health (Lorant et al. 2003, Mirowsky and Ross 2003, Sironi 2012, McFarland and Wagner 2015, Stewart-Brown et al. 2015). In a recent study, Nafilyan et al. (2020) show that the British compulsory schooling reform of 1972 lead to poorer mental health. Their finding suggests that keeping unsuccessful students at school may have adverse effects on their mental health.

Tables 3-11 shows that individuals with higher education have worried feelings less often and less intense. The daily worry prevalence is $11.66 \%$ among individuals without a high school degree and $6.75 \%$ among individuals with a graduate degree beyond a bachelor's degree. For all worry items, there is a negative relationship between the frequency of very worried individuals and education level.

Among all items, worries about paying bills and housing cost are the two worry items most sensitive to education level. The prevalence of high worry about paying bills is $26.29 \%$ among individuals without a high school diploma and $3.33 \%$ among individuals with a graduate degree. Also, the prevalence of high worry about housing cost is $2.79 \%$ among individuals with a graduate degree and $23.20 \%$ among individuals without a high school diploma.

The results presented in this paper contributes to the literature by presenting a more detailed picture of worry and how its association with education level varies across different worry items.

\section{Insurance}

Like any diagnosis, a mental health condition may increase insurance premiums or result in the refusal of an application. Based on an article $^{11}$ by Sun, the premium may triple. The discrimination against people with mental health issues is not uncommon ${ }^{12}$ but causes concerns among policymakers. This discrimination may explain differences between individuals with and without insurance coverage to a degree. Also, not being covered by health insurance may contribute to the increased worry among individuals without insurance.

Table 3 shows that there is no substantial difference in the frequency of worrying feelings between individuals with and without health insurance. On the other hand, Tables 4-11 show that individuals with health insurance report less worry for all worry items. Most noticeably, 43.49 percent of people without health insurance coverage are very worried about medical costs for normal health care compared to 9.66 percent of those with health insurance coverage. Similarly, one in every two $(54.16 \%)$ individuals without health insurance coverage and 17.12 percent of individuals with health insurance coverage are very worried about medical costs due to illness/accident.

The worry gap between individuals with and without health insurance in all worry items suggests that individuals without health insurance have low socioeconomic status. On the other hand, the large gap in worry about medical costs also suggests that not having health insurance may have adverse mental effects. These figures offer new insights into the relationship between health insurance purchases and mental health.

\section{Age}

Contrary to some stereotypes, older adults report significantly fewer worries than younger adults (e.g., Powers et al. 1992, Doucet et al. 1998, Skarborn and Nicki 2000, Hunt et al. 2003, Lindesay et al. 2006, Basevitz et al. 2008, Babcock et al. 2012 and Goncalves et al. 2012).

Table 3 shows that seniors experience worried feelings less often. This result is aligned with the previous findings. Also, seniors are less worried about medical costs for normal healthcare and due to illness/accident despite having more health problems. According to Tables 5 and 6, adults are three times more likely to be very worried about medical costs than seniors. Interestingly, the worry items about medical costs are the items that seniors are far less worried compared to adults. Further research is required to understand this puzzling fact.

\section{Marital Status}

Empirical studies show that marriage has protective effects on health (Turner et al. 1999, Williams 2004, Manzoli et al. 2007). Table 3 supports these findings and shows that married individuals experience worried feelings less often than single,

\footnotetext{
${ }^{11}$ https://www.thesun.co.uk/money/3517732/declaring-mental-health-issues-to-your-insurer-can-raise-premiums-by-200heres-how-to-cut-costs/

${ }^{12}$ https://www.cbc.ca/news/canada/kitchener-waterloo/ontario-man-says-life-insurance-application-denied-due-to-anxietydisorder-1.5238719
} 
widowed, separated/divorced individuals. Interestingly, it also shows that unmarried couples report worried feelings more often than married couples. Married couples report less worry compared to unmarried couples, single and separated/divorced individuals for all worry items. These results confirm the large pool of evidence suggesting that marriage has positive effects on mental health.

Separated/divorced population is the group that worries most frequently. Separated/divorced people also worry more about their living standards than others. Medical costs and paying for children's college cause worry to unmarried couples the most. Finally, paying bills, credit card payments, and housing cost cause worry to single individuals more than the others.

\section{DISCUSSION}

This study shows that excess worry is a common problem in the U.S. Two in every five individuals are very worried about at least one worry item. Also, three quarters of the population are moderately or very worried about at least one worry item. Around one in ten $(9.36 \%)$ individuals aged 25-85 experience worried feelings every day.

The most common worrying factor among the U.S. population is paying for the children's college. Six in every ten $(54.70 \%)$ individuals moderately or very worried about paying for their children's college. Money for retirement is the second most common cause of worry. Money after retirement causes moderate or high worry for 53.46 percent of people. The third most common cause of worry is medical cost due to illness/accident. Nearly half of the population $(47.38 \%)$ is moderately or very worried about unexpected medical costs due to illness/accident. The least common cause of worry is housing cost $(26.82 \%)$.

These results indicate that providing access to an affordable college education may improve mental health in the society. They also show the importance of financial planning and wellfunctioning retirement funds on for the general mental health. Finally, they highlight the importance of health insurance with an inclusive coverage plan to reduce worry about medical cost due to illness/accident.

\section{REFERENCES}

[1] Assari, S. Separate and combined effects of anxiety, depression and problem drinking on subjective health among Black, Hispanic and non-Hispanic White men. Int J Prev Med. 5(3), 269-79 (2014).

[2] Assari, S. Social Determinants of Depression: The Intersections of Race, Gender, and Socioeconomic Status. Brain Sciences 7(12) (2017).

[3] Assari, S., Dejman, M. \& Neighbors, H.W. Ethnic differences in separate and additive effects of anxiety and depression on self-rated mental health among Blacks. J Racial Ethn Health Disparities 3(3), 423-30 (2016).

[4] Assari, S. \& Lankarani, M.M. Demographic and Socioeconomic Determinants of Physical and Mental Self- rated Health Across 10 Ethnic Groups in the United States. Int J Epidemiol Res 3(12), 185-193 (2019).

[5] Assari, S., Lapeyrouse, L.M. \& Neighbors, H.W. Income and selfrated mental health: diminished returns for high income black Americans. Behav Sci (Basel) 8(5) (2018).

[6] Avendano, M., De Coulon, A. \& Nafilyan, V. L. Does longer compulsory schooling affect mental health? Evidence from a British reform. Journal of Public Economy 183, 1-34 (Mar, 2020).

[7] Babcock, R.L., MaloneBeach, E.E., Hou, B., \& Smith, M. The experience of worry among young and older adults in the United States and Germany: A cross-national comparison. Aging \& Mental Health 16, 413-422 (2012).

[8] Basevitz, P., Pushkar, D., Chaikelson, J., Conway, M., \& Dalton, C. Age-related differences in worry and related processes. International Journal of Aging \& Human Development 66, 283-305 (2008).

[9] Blue, L. \& Fenelon, A. Explaining low mortality among U.S. immigrants relative to native-born Americans: the role of smoking. Int J Epidemiol 40(3),786-93 (Jun, 2011).

[10] Borkovec, T.D., Robinson, E., Pruzinsky, T. \& DePree, J. A. Preliminary exploration of worry: Some characteristics and processes. Behaviour Research and Therapy 21(1), 9-16 (1983).

[11] Cobb, S. \& Assari, S. Investigation of the Predictors of Self-rated Health of Economically Disadvantaged African American Men and Women: Evidence for Sponge Hypothesis. Int J Epidemiol Res. 7(1), 25-34 (2020).

[12] Demirchyan, A., Petrosyan, V. \& Thompson, M.E. Gender differences in predictors of self-rated health in Armenia: a population-based study of an economy in transition. Int J Equity Health 11, 67 (2012).

[13] Filion, N., Fenelon, A. \& Boudreaux, M. Immigration, citizenship, and the mental health of adolescents. PLoS One 13(5), (2018).

[14] Lindesay, J., Baillon, S., Brugha, T., Dennis, M., Stewart, R., Araya, R., \& Meltzer, H. Worry content across the lifespan: An analysis of 16- to 74-yearold participants in the British National Survey of Psychiatric Morbidity 2000. Psychological Medicine 36, 1625-1633 (2006).

[15] Lynn A., Blewett, Julia A., Rivera Drew, Miriam L. King \& Kari C.W. Williams. IPUMS Health Surveys: National Health Interview Survey, Version 6.4 [dataset]. Minneapolis, MN: IPUMS. (2019)

[15] Hovatta, I., Juhila, J. \& Donner, J. Oxidative stress in anxiety and comorbid disorders Neurosci. Res. 68(4), 261-75 (Dec, 2010).

[16] Lorant, V., Deliege, D., Eaton, W., Robert, A., Philippot, P. \& Ansseau, M. Socioeconomic inequalities in depression: A meta-analysis, American Journal of Epidemiology 157(2), 98-112 (2003). 
[17] Manzoli, L., Villari, P., Pirone G.M. \& Boccia, A. Marital status and mortality in the elderly: a systematic review and meta-analysis. Social Science \& Medicine 64, 77-94 (2007).

[18] McFarland, M.J. \& Wagner, B.G. Does a college education reduce depressive symptoms in American young adults?. Soc Sci Med. 146:75-84 (2015).

[19] Miloyan, B. \& Pachana, N.A. Clinical significance of worry and physical symptoms in late-life generalized anxiety disorder. International Journal of Geriatric Psychiatry 30, 1186-1194 (2015).

[20] Mirowsky, J. \&Ross, C. E., Social Causes of Psychological Distress. Aldine de Gruyter (2003).

[21] Moylan, S., Jacka, F.N., Pasco, J.A. \& Berk, M. How cigarette smoking may increase the risk of anxiety symptoms and anxiety disorders: a critical review of biological pathways. Brain Behavior 3, 302-326 (2013).

[22] Olfson, M., Marcus, S.C., Tedeschi, M. \& Wan, G.J. Continuity of antidepressant treatment for adults with depression in the United States. Am J Psychiatr. 163:101-8 (2006)

[23] Rios, R. \& Zautra, A.J. Socioeconomic disparities in pain: The role of economic hardship and daily financial worry. Health Psychology 30, 58-66 (2011).

[24] Rodriquez, E. J., Livaudais-Toman, J., Gregorich, S. E., Jackson, J. S., Nápoles, A. M., \& Pérez-Stable, E. J. Relationships between allostatic load, unhealthy behaviors, and depressive disorder in U.S. adults, 2005-2012 NHANES. Preventive Medicine, 110, 9-15 (2018).

[25] Schulz, A.J., Gravlee, C.C., Williams, D.R., Israel, B.A., Mentz, G. \& Rowe, Z. Discrimination, symptoms of depression, and self-rated health among african american women in detroit: results from a longitudinal analysis. Am J Public Health 96(7) (2006).

[26] Singh, G.K., Yu, S.M. \& Kogan M.D. (2013): Health, chronic conditions, and behavioral risk disparities among U.S. immigrant children and adolescents. Public Health Rep 128(6), 463-79 (2013).

[27] Sironi, M. Education and Mental Health in Europe. International Journal of Mental Health 41(3), 79-105 (2012).

[28] Stedman, R.L. The chemical composition of tobacco and tobacco smoke. Chem Rev. Apr 68(2): 153-207 (1968).

[29] Stewart-Brown, S., Samaraweera, P. C., Taggart, F., Kandala, N. B. \&Stranges, S., Socioeconomic gradients and mental health: Implications for public health. British Journal of Psychiatry 206(6), 461-465 (2015).

[30] Taylor, G., McNeill, A. \& Girling, A. Change in mental health after smoking cessation: systematic review and metaanalysis. British Medical Journal 348, g1151 (2014).

[31] Turner, R.J. \& Gil, A.G. Psychiatric and substance use disorders in South Florida: racial/ethnic and gender contrasts in a young adult cohort. Arch Gen Psychiatry 59(1), 43-50 (Jan, 2002).

[32] Turner, R.J., Lloyd, D.A. \& Roszell, P. Personal resources and the social distribution of depression. American Journal of Community Psychology 27(5), 643-672 (1999).

[33] Weissman, J., Russell, D. \& Mann, J.J. Sociodemographic Characteristics, Financial Worries and Serious Psychological Distress in U.S. Adults. Community Ment Health J. 56(4), 606-613 (2020).

[34] Williams K. The transition to widowhood and the social regulation of health: consequences for health and health risk behaviour. The Journals of Gerontology Series B, Psychological Sciences and Social Sciences, 59(6): S343-349 (2004).

[35] Williams, M. T., Chapman, L. K., Wong, J. \& Turkheimer, E. The role of ethnic identity in symptoms of anxiety and depression in African Americans. Psychiatry research, 199(1), 31-36 (2012).

[36] Wisocki, P.A. Worry as a Phenomenon Relevant to the Elderly. Behavior Therapy 19, 369-379 (1988). 
Table 3. Worry Frequency

\begin{tabular}{|c|c|c|c|c|c|}
\hline & Daily & Weekly & Monthly & $\begin{array}{c}\text { A few times a } \\
\text { year }\end{array}$ & Never \\
\hline \multicolumn{6}{|l|}{ Gender } \\
\hline Women & $11.21 \%$ & $13.57 \%$ & $10.93 \%$ & $29.93 \%$ & $34.37 \%$ \\
\hline Men & $7.21 \%$ & $9.48 \%$ & $8.12 \%$ & $29.87 \%$ & $45.32 \%$ \\
\hline \multicolumn{6}{|l|}{ Race } \\
\hline White American & $9.99 \%$ & $12.74 \%$ & $10.30 \%$ & $29.72 \%$ & $37.25 \%$ \\
\hline African American & $7.75 \%$ & $7.91 \%$ & $7.27 \%$ & $29.68 \%$ & $47.39 \%$ \\
\hline Native American & $11.14 \%$ & $11.95 \%$ & $4.94 \%$ & $33.48 \%$ & $38.49 \%$ \\
\hline Asian American & $4.97 \%$ & $7.21 \%$ & $7.77 \%$ & $31.80 \%$ & $48.24 \%$ \\
\hline \multicolumn{6}{|l|}{ Hispanic } \\
\hline Hispanic & $7.30 \%$ & $9.06 \%$ & $8.18 \%$ & $28.14 \%$ & $47.31 \%$ \\
\hline Not Hispanic & $9.80 \%$ & $12.23 \%$ & $9.94 \%$ & $30.28 \%$ & $37.75 \%$ \\
\hline \multicolumn{6}{|l|}{ Insurance } \\
\hline Insurance $=$ Yes & $9.14 \%$ & $11.79 \%$ & $9.84 \%$ & $30.11 \%$ & $39.13 \%$ \\
\hline Insurance $=N o$ & $10.77 \%$ & $10.92 \%$ & $8.26 \%$ & $28.54 \%$ & $41.50 \%$ \\
\hline \multicolumn{6}{|l|}{ Citizen } \\
\hline Citizen $=$ Yes & $9.81 \%$ & $12.20 \%$ & $9.80 \%$ & $29.94 \%$ & $38.25 \%$ \\
\hline Citizen $=$ No & $5.43 \%$ & $7.11 \%$ & $8.12 \%$ & $29.54 \%$ & $49.80 \%$ \\
\hline \multicolumn{6}{|l|}{ Education } \\
\hline Less than high school & $11.66 \%$ & $8.69 \%$ & $7.66 \%$ & $25.00 \%$ & $46.99 \%$ \\
\hline High school & $10.12 \%$ & $10.92 \%$ & $8.07 \%$ & $27.38 \%$ & $43.51 \%$ \\
\hline Some college & $11.11 \%$ & $11.36 \%$ & $9.78 \%$ & $30.24 \%$ & $37.50 \%$ \\
\hline College & $7.03 \%$ & $13.08 \%$ & $10.47 \%$ & $32.61 \%$ & $36.81 \%$ \\
\hline Post-college & $6.75 \%$ & $13.25 \%$ & $11.55 \%$ & $31.95 \%$ & $36.51 \%$ \\
\hline \multicolumn{6}{|l|}{ Age Groups } \\
\hline Adult & $9.43 \%$ & $11.97 \%$ & $9.85 \%$ & $30.19 \%$ & $38.56 \%$ \\
\hline Senior & $7.92 \%$ & $6.13 \%$ & $5.51 \%$ & $24.46 \%$ & $55.99 \%$ \\
\hline \multicolumn{6}{|l|}{ Marital Status } \\
\hline Single & $12.58 \%$ & $12.33 \%$ & $8.57 \%$ & $27.23 \%$ & $39.28 \%$ \\
\hline Married & $7.36 \%$ & $11.06 \%$ & $9.90 \%$ & $31.15 \%$ & $40.54 \%$ \\
\hline Partnership & $11.18 \%$ & $13.02 \%$ & $9.84 \%$ & $28.49 \%$ & $37.47 \%$ \\
\hline Separated/Divorced & $13.21 \%$ & $13.04 \%$ & $9.65 \%$ & $28.48 \%$ & $35.62 \%$ \\
\hline Widowed & $12.70 \%$ & $10.95 \%$ & $7.13 \%$ & $25.17 \%$ & $44.05 \%$ \\
\hline \multicolumn{6}{|l|}{ Smoking Status } \\
\hline Never & $6.85 \%$ & $10.48 \%$ & $9.47 \%$ & $30.65 \%$ & $42.56 \%$ \\
\hline Former & $10.01 \%$ & $13.10 \%$ & $10.36 \%$ & $30.98 \%$ & $35.56 \%$ \\
\hline Some-day & $12.54 \%$ & $14.28 \%$ & $10.66 \%$ & $30.66 \%$ & $31.86 \%$ \\
\hline Every-day & $19.85 \%$ & $14.61 \%$ & $8.95 \%$ & $24.24 \%$ & $32.34 \%$ \\
\hline Overall & $9.35 \%$ & $11.67 \%$ & $9.63 \%$ & $29.90 \%$ & $39.45 \%$ \\
\hline
\end{tabular}


Table 4. Worried about maintaining the living standard

\begin{tabular}{llccc}
\hline & $\begin{array}{c}\text { Very } \\
\text { worried }\end{array}$ & $\begin{array}{c}\text { Moderately } \\
\text { worried }\end{array}$ & Not too worried & $\begin{array}{c}\text { Not worried } \\
\text { at all }\end{array}$ \\
\hline Gender & & & & \\
Women & $17.80 \%$ & $26.47 \%$ & $29.81 \%$ & $25.93 \%$ \\
Men & $13.56 \%$ & $25.37 \%$ & $32.02 \%$ & $29.04 \%$ \\
\hline Race & & & & \\
White American & $15.28 \%$ & $26.00 \%$ & $31.15 \%$ & $27.57 \%$ \\
$\quad$ African American & $20.30 \%$ & $25.52 \%$ & $28.13 \%$ & $26.05 \%$ \\
$\quad$ Native American & $22.11 \%$ & $20.76 \%$ & $30.11 \%$ & $27.02 \%$ \\
Asian American & $11.40 \%$ & $27.54 \%$ & $33.14 \%$ & $27.93 \%$ \\
\hline Hispanic & & & & \\
$\quad$ Hispanic & $24.84 \%$ & $28.72 \%$ & $25.67 \%$ & $20.77 \%$ \\
$\quad$ Not Hispanic & $13.89 \%$ & $25.36 \%$ & $31.95 \%$ & $28.79 \%$ \\
\hline Insurance & & & & $29.09 \%$ \\
Insurance = Yes & $13.02 \%$ & $25.78 \%$ & $32.11 \%$ & $16.12 \%$ \\
Insurance = No & $34.22 \%$ & $27.12 \%$ & $22.54 \%$ &
\end{tabular}

\section{Citizen}

\begin{tabular}{lllll} 
Citizen $=$ Yes & $14.81 \%$ & $25.69 \%$ & $31.30 \%$ & $28.20 \%$ \\
Citizen $=$ No & $24.64 \%$ & $28.30 \%$ & $26.83 \%$ & $20.22 \%$ \\
\hline Education & & & & \\
Less than high school & $27.69 \%$ & $26.06 \%$ & $23.86 \%$ & $22.39 \%$ \\
High school & $20.22 \%$ & $27.44 \%$ & $26.42 \%$ & $25.91 \%$ \\
Some college & $18.14 \%$ & $26.26 \%$ & $29.88 \%$ & $25.72 \%$ \\
College & $9.41 \%$ & $25.26 \%$ & $36.35 \%$ & $28.98 \%$ \\
Post-college & $6.72 \%$ & $24.34 \%$ & $35.18 \%$ & $33.75 \%$ \\
\hline
\end{tabular}

\section{Age Groups}

\begin{tabular}{lllll} 
Adult & $16.35 \%$ & $26.44 \%$ & $31.12 \%$ & $26.09 \%$ \\
\multicolumn{1}{c}{ Senior } & $6.28 \%$ & $17.00 \%$ & $25.52 \%$ & $51.12 \%$ \\
\hline $\begin{array}{l}\text { Marital Status } \\
\text { Single }\end{array}$ & $22.74 \%$ & $25.07 \%$ & $27.53 \%$ & $24.66 \%$ \\
Married & $11.72 \%$ & $25.56 \%$ & $33.83 \%$ & $28.89 \%$ \\
Partnership & $21.96 \%$ & $27.16 \%$ & $27.09 \%$ & $23.78 \%$ \\
Separated/Divorced & $23.41 \%$ & $28.06 \%$ & $24.76 \%$ & $23.78 \%$ \\
Widowed & $17.41 \%$ & $22.82 \%$ & $23.00 \%$ & $36.78 \%$ \\
\hline Smoking Status & & & & \\
Never & $13.19 \%$ & $25.79 \%$ & $32.78 \%$ & $28.24 \%$ \\
Former & $15.14 \%$ & $26.21 \%$ & $29.98 \%$ & $28.67 \%$ \\
Some-day & $21.84 \%$ & $24.67 \%$ & $29.39 \%$ & $24.10 \%$ \\
Every-day & $28.28 \%$ & $26.82 \%$ & $22.90 \%$ & $21.99 \%$ \\
\hline Overall & $15.84 \%$ & $25.96 \%$ & $30.84 \%$ & $27.37 \%$ \\
\hline
\end{tabular}


Table 5. Worried about medical cost due to illness/accident

\begin{tabular}{lcccc}
\hline & $\begin{array}{c}\text { Very } \\
\text { worried }\end{array}$ & $\begin{array}{c}\text { Moderately } \\
\text { worried }\end{array}$ & Not too worried & $\begin{array}{c}\text { Not worried } \\
\text { at all }\end{array}$ \\
\hline Gender & & & & \\
Women & $24.87 \%$ & $25.22 \%$ & $24.02 \%$ & $25.89 \%$ \\
Men & $18.78 \%$ & $25.48 \%$ & $25.76 \%$ & $29.98 \%$ \\
\hline Race & & & & \\
White American & $21.82 \%$ & $25.44 \%$ & $24.89 \%$ & $27.85 \%$ \\
African American & $25.36 \%$ & $24.08 \%$ & $23.44 \%$ & $27.12 \%$ \\
Native American & $25.08 \%$ & $23.10 \%$ & $20.82 \%$ & $31.00 \%$ \\
Asian American & $16.76 \%$ & $27.41 \%$ & $27.97 \%$ & $27.86 \%$ \\
\hline
\end{tabular}

\section{Hispanic}

\begin{tabular}{lllll} 
Hispanic & $35.60 \%$ & $24.82 \%$ & $19.06 \%$ & $20.52 \%$ \\
Not Hispanic & $19.11 \%$ & $25.45 \%$ & $26.07 \%$ & $29.36 \%$ \\
\hline Insurance & & & & \\
$\quad \begin{array}{l}\text { Insurance }=\text { Yes } \\
\text { Insurance }=\text { No }\end{array}$ & $17.12 \%$ & $25.84 \%$ & $26.79 \%$ & $30.25 \%$ \\
\hline
\end{tabular}

\section{Citizen}

\begin{tabular}{|c|c|c|c|c|}
\hline Citizen $=$ Yes & $20.11 \%$ & $25.46 \%$ & $25.52 \%$ & $28.91 \%$ \\
\hline Citizen $=$ No & $38.70 \%$ & $24.33 \%$ & $18.84 \%$ & $18.14 \%$ \\
\hline \multicolumn{5}{|l|}{ Education } \\
\hline Less than high school & $37.78 \%$ & $20.52 \%$ & $18.65 \%$ & $23.05 \%$ \\
\hline High school & $27.81 \%$ & $23.96 \%$ & $21.94 \%$ & $26.28 \%$ \\
\hline Some college & $24.98 \%$ & $26.54 \%$ & $22.82 \%$ & $25.66 \%$ \\
\hline College & $13.44 \%$ & $27.78 \%$ & $29.20 \%$ & $29.58 \%$ \\
\hline Post-college & $10.36 \%$ & $24.49 \%$ & $30.39 \%$ & $34.75 \%$ \\
\hline \multicolumn{5}{|l|}{ Age Groups } \\
\hline Adult & $22.79 \%$ & $25.88 \%$ & $24.85 \%$ & $26.48 \%$ \\
\hline Senior & $8.08 \%$ & $15.24 \%$ & $24.37 \%$ & $52.31 \%$ \\
\hline \multicolumn{5}{|l|}{ Marital Status } \\
\hline Single & $28.96 \%$ & $22.28 \%$ & $22.38 \%$ & $26.38 \%$ \\
\hline Married & $17.74 \%$ & $26.11 \%$ & $27.20 \%$ & $28.95 \%$ \\
\hline Partner & $31.50 \%$ & $25.67 \%$ & $19.75 \%$ & $23.08 \%$ \\
\hline Separated/Divorced & $29.40 \%$ & $25.59 \%$ & $20.42 \%$ & $24.60 \%$ \\
\hline Widowed & $20.19 \%$ & $18.46 \%$ & $20.95 \%$ & $40.40 \%$ \\
\hline \multicolumn{5}{|l|}{ Smoking Status } \\
\hline Never & $19.45 \%$ & $26.12 \%$ & $26.41 \%$ & $28.03 \%$ \\
\hline Former & $21.14 \%$ & $24.89 \%$ & $24.34 \%$ & $29.63 \%$ \\
\hline Some-day & $26.58 \%$ & $25.18 \%$ & $23.25 \%$ & $25.00 \%$ \\
\hline Every-day & $35.00 \%$ & $22.23 \%$ & $18.18 \%$ & $24.59 \%$ \\
\hline Overall & $22.04 \%$ & $25.34 \%$ & $24.83 \%$ & $27.79 \%$ \\
\hline
\end{tabular}


Table 6. Worried about the medical cost for normal healthcare

\begin{tabular}{lcccc}
\hline & $\begin{array}{c}\text { Very } \\
\text { worried }\end{array}$ & $\begin{array}{c}\text { Moderately } \\
\text { worried }\end{array}$ & Not too worried & $\begin{array}{c}\text { Not worried } \\
\text { at all }\end{array}$ \\
\hline $\begin{array}{l}\text { Gender } \\
\text { Women }\end{array}$ & $15.46 \%$ & $18.51 \%$ & $27.93 \%$ & $38.09 \%$ \\
Men & $12.65 \%$ & $17.34 \%$ & $29.28 \%$ & $40.74 \%$ \\
\hline Race & & & & \\
$\quad$ White American & $13.80 \%$ & $17.60 \%$ & $28.54 \%$ & $40.07 \%$ \\
$\quad$ African American & $17.81 \%$ & $19.44 \%$ & $27.72 \%$ & $35.03 \%$ \\
$\quad$ Native American & $20.27 \%$ & $17.96 \%$ & $23.87 \%$ & $37.89 \%$ \\
Asian American & $9.19 \%$ & $19.09 \%$ & $31.58 \%$ & $40.14 \%$ \\
\hline
\end{tabular}

Hispanic

\begin{tabular}{lllll} 
Hispanic & $25.62 \%$ & $22.98 \%$ & $23.89 \%$ & $27.51 \%$ \\
Not Hispanic & $11.68 \%$ & $16.88 \%$ & $29.56 \%$ & $41.87 \%$ \\
\hline Insurance & & & & \\
$\quad$ Insurance $=$ Yes & $9.66 \%$ & $17.01 \%$ & $30.37 \%$ & $42.96 \%$ \\
Insurance $=$ No & $43.49 \%$ & $24.21 \%$ & $16.72 \%$ & $15.58 \%$ \\
\hline
\end{tabular}

\section{Citizen}

$\begin{array}{lllll}\text { Citizen }=\text { Yes } & 12.64 \% & 17.35 \% & 29.16 \% & 40.85 \% \\ \text { Citizen }=\text { No } & 27.22 \% & 23.29 \% & 23.31 \% & 26.17 \%\end{array}$

\section{Education}

$\begin{array}{lllll}\text { Less than high school } & 28.70 \% & 20.93 \% & 21.90 \% & 28.46 \% \\ \text { High school } & 18.88 \% & 20.80 \% & 26.11 \% & 34.20 \% \\ \text { Some college } & 15.93 \% & 19.35 \% & 27.92 \% & 36.80 \% \\ \text { College } & 7.19 \% & 15.46 \% & 32.65 \% & 44.70 \% \\ \text { Post-college } & 4.55 \% & 13.10 \% & 31.57 \% & 50.78 \%\end{array}$

\section{Age Groups}

\begin{tabular}{lllll} 
Adult & $14.67 \%$ & $18.25 \%$ & $28.71 \%$ & $38.37 \%$ \\
Senior & $4.56 \%$ & $12.75 \%$ & $25.64 \%$ & $57.05 \%$ \\
\hline $\begin{array}{l}\text { Marital Status } \\
\text { Single }\end{array}$ & $19.80 \%$ & $19.13 \%$ & $26.51 \%$ & $34.56 \%$ \\
Married & $10.74 \%$ & $17.09 \%$ & $30.37 \%$ & $41.80 \%$ \\
Partnership & $20.70 \%$ & $20.63 \%$ & $24.94 \%$ & $33.73 \%$ \\
Separated/Divorced & $19.96 \%$ & $19.66 \%$ & $25.32 \%$ & $35.06 \%$ \\
Widowed & $15.08 \%$ & $15.39 \%$ & $24.83 \%$ & $44.71 \%$
\end{tabular}

\section{Smoking Status}

\begin{tabular}{lllll} 
Never & $12.32 \%$ & $17.61 \%$ & $29.62 \%$ & $40.46 \%$ \\
Former & $12.27 \%$ & $17.93 \%$ & $29.17 \%$ & $40.64 \%$ \\
Some-day & $18.69 \%$ & $19.00 \%$ & $27.10 \%$ & $35.21 \%$ \\
Every-day & $24.88 \%$ & $19.51 \%$ & $22.74 \%$ & $32.88 \%$ \\
\hline Overall & $14.16 \%$ & $17.97 \%$ & $28.56 \%$ & $39.32 \%$ \\
\hline
\end{tabular}


Table 7. Worried about paying bills

\begin{tabular}{lcccc}
\hline & $\begin{array}{c}\text { Very } \\
\text { worried }\end{array}$ & $\begin{array}{c}\text { Moderately } \\
\text { worried }\end{array}$ & Not too worried & $\begin{array}{c}\text { Not worried } \\
\text { at all }\end{array}$ \\
\hline $\begin{array}{l}\text { Gender } \\
\text { Women }\end{array}$ & $14.19 \%$ & $21.60 \%$ & $27.92 \%$ & $36.29 \%$ \\
Men & $10.15 \%$ & $18.32 \%$ & $29.71 \%$ & $41.81 \%$ \\
\hline Race & & & & \\
White American & $11.40 \%$ & $19.46 \%$ & $28.88 \%$ & $40.27 \%$ \\
$\quad$ African American & $18.20 \%$ & $23.71 \%$ & $27.05 \%$ & $31.05 \%$ \\
$\quad$ Native American & $19.69 \%$ & $22.49 \%$ & $25.55 \%$ & $32.27 \%$ \\
Asian American & $8.85 \%$ & $19.03 \%$ & $31.64 \%$ & $40.48 \%$ \\
\hline
\end{tabular}

\section{Hispanic}

\begin{tabular}{|c|c|c|c|c|}
\hline Hispanic & $21.64 \%$ & $26.19 \%$ & $26.42 \%$ & $25.75 \%$ \\
\hline Not Hispanic & $10.31 \%$ & $18.76 \%$ & 29.255 & $41.68 \%$ \\
\hline \multicolumn{5}{|l|}{ Insurance } \\
\hline Insurance $=$ Yes & $9.77 \%$ & $18.97 \%$ & $29.63 \%$ & $41.63 \%$ \\
\hline Insurance $=$ No & $28.94 \%$ & $27.31 \%$ & $23.04 \%$ & $20.71 \%$ \\
\hline \multicolumn{5}{|l|}{ Citizen } \\
\hline Citizen $=$ Yes & $11.19 \%$ & $19.47 \%$ & $29.00 \%$ & $40.34 \%$ \\
\hline Citizen $=N o$ & $22.08 \%$ & $25.32 \%$ & $26.61 \%$ & $25.99 \%$ \\
\hline \multicolumn{5}{|l|}{ Education } \\
\hline Less than high school & $26.29 \%$ & $26.13 \%$ & $24.15 \%$ & $23.43 \%$ \\
\hline High school & $16.94 \%$ & $24.37 \%$ & $26.49 \%$ & $32.20 \%$ \\
\hline Some college & $13.95 \%$ & $22.26 \%$ & $28.33 \%$ & $35.47 \%$ \\
\hline College & $5.50 \%$ & $15.78 \%$ & $31.97 \%$ & $46.76 \%$ \\
\hline Post-college & $3.33 \%$ & $12.22 \%$ & $30.98 \%$ & $53.48 \%$ \\
\hline \multicolumn{5}{|l|}{ Age Groups } \\
\hline Adult & $12.74 \%$ & $20.42 \%$ & $28.99 \%$ & $37.85 \%$ \\
\hline Senior & $4.50 \%$ & $13.66 \%$ & $24.30 \%$ & $57.54 \%$ \\
\hline \multicolumn{5}{|l|}{ Marital Status } \\
\hline Single & $20.34 \%$ & $24.70 \%$ & $26.43 \%$ & $28.53 \%$ \\
\hline Married & $8.27 \%$ & $17.80 \%$ & $30.52 \%$ & $43.41 \%$ \\
\hline Partnership & $17.63 \%$ & $24.25 \%$ & $28.33 \%$ & $29.79 \%$ \\
\hline Separated/Divorced & $19.03 \%$ & $23.71 \%$ & $24.74 \%$ & $32.53 \%$ \\
\hline Widowed & $14.78 \%$ & $18.53 \%$ & $23.68 \%$ & $43.01 \%$ \\
\hline \multicolumn{5}{|l|}{ Smoking Status } \\
\hline Never & $10.24 \%$ & $19.03 \%$ & $30.03 \%$ & $40.69 \%$ \\
\hline Former & $10.18 \%$ & $19.02 \%$ & $29.13 \%$ & $41.68 \%$ \\
\hline Some-day & $16.95 \%$ & $24.57 \%$ & $28.08 \%$ & $30.40 \%$ \\
\hline Every-day & $24.58 \%$ & $25.57 \%$ & $21.96 \%$ & $27.89 \%$ \\
\hline Overall & $12.32 \%$ & $20.08 \%$ & $28.75 \%$ & $38.85 \%$ \\
\hline
\end{tabular}


Table 8. Worried about credit card payments (only credit cardholders)

\begin{tabular}{lcccc}
\hline & $\begin{array}{c}\text { Very } \\
\text { worried }\end{array}$ & $\begin{array}{c}\text { Moderately } \\
\text { worried }\end{array}$ & Not too worried & $\begin{array}{c}\text { Not worried } \\
\text { at all }\end{array}$ \\
\hline $\begin{array}{l}\text { Gender } \\
\text { Women }\end{array}$ & & & \\
Men & $13.31 \%$ & $24.16 \%$ & $54.32 \%$ & $8.22 \%$ \\
\hline Race & $10.50 \%$ & $24.74 \%$ & $58.32 \%$ & $6.45 \%$ \\
$\quad$ White American & & & & \\
African American & $11.31 \%$ & $23.81 \%$ & $58.21 \%$ & $6.67 \%$ \\
Native American & $15.77 \%$ & $26.15 \%$ & $46.37 \%$ & $11.70 \%$ \\
Asian American & $12.68 \%$ & $23.62 \%$ & $47.92 \%$ & $15.78 \%$ \\
\hline
\end{tabular}

\section{Hispanic}

\begin{tabular}{llllc} 
Hispanic & $18.91 \%$ & $23.88 \%$ & $41.85 \%$ & $15.35 \%$ \\
Not Hispanic & $10.72 \%$ & $24.53 \%$ & $58.80 \%$ & $5.94 \%$ \\
\hline Insurance & & & & \\
Insurance $=$ Yes & $10.96 \%$ & $24.77 \%$ & $58.15 \%$ & $6.12 \%$ \\
Insurance $=$ No & $21.77 \%$ & $21.13 \%$ & $37.43 \%$ & $19.67 \%$ \\
\hline
\end{tabular}

\section{Citizen}

$\begin{array}{llllr}\text { Citizen }=\text { Yes } & 11.38 \% & 24.39 \% & 57.49 \% & 6.74 \% \\ \text { Citizen }=\text { No } & 18.10 \% & 24.86 \% & 43.04 \% & 14.00 \%\end{array}$

\section{Education}

\begin{tabular}{llllc} 
Less than high school & $18.81 \%$ & $24.64 \%$ & $39.53 \%$ & $17.02 \%$ \\
High school & $15.64 \%$ & $23.86 \%$ & $49.34 \%$ & $11.16 \%$ \\
Some college & $14.27 \%$ & $24.48 \%$ & $52.35 \%$ & $8.90 \%$ \\
College & $9.00 \%$ & $24.96 \%$ & $61.96 \%$ & $4.08 \%$ \\
Post-college & $6.42 \%$ & $24.04 \%$ & $67.19 \%$ & $2.35 \%$ \\
\hline
\end{tabular}

\section{Age Groups}

\begin{tabular}{|c|c|c|c|c|}
\hline Adult & $12.20 \%$ & $24.60 \%$ & $55.56 \%$ & $7.63 \%$ \\
\hline Senior & $7.86 \%$ & $21.51 \%$ & $67.80 \%$ & $2.82 \%$ \\
\hline \multicolumn{5}{|l|}{ Marital Status } \\
\hline Single & $15.84 \%$ & $25.71 \%$ & $46.83 \%$ & $11.62 \%$ \\
\hline Married & $10.73 \%$ & $24.74 \%$ & $59.53 \%$ & $5.00 \%$ \\
\hline Partnership & $13.82 \%$ & $23.75 \%$ & $50.31 \%$ & $12.12 \%$ \\
\hline Separated/Divorced & $14.87 \%$ & $22.65 \%$ & $49.15 \%$ & $13.34 \%$ \\
\hline Widowed & $9.02 \%$ & $23.42 \%$ & $58.28 \%$ & $9.28 \%$ \\
\hline \multicolumn{5}{|l|}{ Smoking Status } \\
\hline Never & $11.76 \%$ & $24.93 \%$ & $56.87 \%$ & $6.44 \%$ \\
\hline Former & $10.88 \%$ & $23.42 \%$ & $59.56 \%$ & $6.14 \%$ \\
\hline Some-day & $13.75 \%$ & $26.42 \%$ & $50.29 \%$ & $9.54 \%$ \\
\hline Every-day & $15.19 \%$ & $46.46 \%$ & $22.36 \%$ & $15.19 \%$ \\
\hline Overall & $11.96 \%$ & $24.43 \%$ & $56.23 \%$ & $7.37 \%$ \\
\hline
\end{tabular}


Table 9. Worried about rent/mortgage/housing cost

\begin{tabular}{lcccc}
\hline & $\begin{array}{c}\text { Very } \\
\text { worried }\end{array}$ & $\begin{array}{c}\text { Moderately } \\
\text { worried }\end{array}$ & Not too worried & $\begin{array}{c}\text { Not worried } \\
\text { at all }\end{array}$ \\
\hline Gender & & & & \\
Women & $12.03 \%$ & $17.03 \%$ & $28.18 \%$ & $42.77 \%$ \\
Men & $9.03 \%$ & $15.90 \%$ & $28.98 \%$ & $46.80 \%$ \\
\hline Race & & & & \\
White American & $9.70 \%$ & $15.41 \%$ & $28.53 \%$ & $46.36 \%$ \\
African American & $15.95 \%$ & $20.05 \%$ & $27.36 \%$ & $36.64 \%$ \\
$\quad$ Native American & $16.58 \%$ & $16.67 \%$ & $21.71 \%$ & $45.04 \%$ \\
Asian American & $8.85 \%$ & $16.67 \%$ & $32.79 \%$ & $41.69 \%$ \\
\hline
\end{tabular}

\section{Hispanic}

\begin{tabular}{ccccc} 
Hispanic & $20.12 \%$ & $22.90 \%$ & $26.65 \%$ & $30.32 \%$ \\
Not Hispanic & $8.59 \%$ & $14.73 \%$ & $28.96 \%$ & $47.73 \%$ \\
\hline Insurance & & & & \\
$\quad \begin{array}{l}\text { Insurance }=\text { Yes } \\
\text { Insurance }=\text { No }\end{array}$ & $8.34 \%$ & $15.02 \%$ & $29.10 \%$ & $47.54 \%$ \\
\hline
\end{tabular}

\section{Citizen}

$\begin{array}{lllll}\text { Citizen }=\text { Yes } & 9.48 \% & 15.32 \% & 28.72 \% & 46.48 \% \\ \text { Citizen }=\text { No } & 20.57 \% & 23.56 \% & 27.08 \% & 28.80 \%\end{array}$

\section{Education}

Less than high school

$23.20 \%$

$22.61 \%$

$25.32 \%$

$28.87 \%$

High school

$14.51 \%$

$20.08 \%$

$26.80 \%$

$38.62 \%$

Some college

$12.03 \%$

$17.23 \%$

$28.53 \%$

$42.21 \%$

College

$4.68 \%$

$12.67 \%$

$30.76 \%$

$51.89 \%$

Post-college

$2.79 \%$

$9.62 \%$

$29.83 \%$

$57.76 \%$

Age Groups

$\begin{array}{lllll}\text { Adult } & 10.98 \% & 16.52 \% & 28.81 \% & 43.68 \% \\ \text { Senior } & 4.22 \% & 9.81 \% & 23.56 \% & 62.42 \%\end{array}$

\section{Marital Status}

Single

$17.16 \%$

$19.94 \%$

$27.88 \%$

$35.03 \%$

Married

$7.16 \%$

$14.35 \%$

$29.87 \%$

$48.62 \%$

Partnership

$15.18 \%$

$19.73 \%$

$27.24 \%$

$37.85 \%$

Separated/Divorced

$16.50 \%$

$19.19 \%$

$25.29 \%$

$39.02 \%$

Widowed

$13.75 \%$

$13.39 \%$

$24.06 \%$

$48.80 \%$

\section{Smoking Status}

\begin{tabular}{lllll} 
Never & $9.17 \%$ & $15.75 \%$ & $29.46 \%$ & $45.62 \%$ \\
Former & $8.41 \%$ & $14.90 \%$ & $28.11 \%$ & $48.58 \%$ \\
Some-day & $14.81 \%$ & $17.82 \%$ & $28.33 \%$ & $39.04 \%$ \\
Every-day & $20.11 \%$ & $19.77 \%$ & $24.74 \%$ & $35.38 \%$ \\
\hline Overall & $10.64 \%$ & $16.18 \%$ & $28.55 \%$ & $44.64 \%$ \\
\hline
\end{tabular}


Table 10. Worried about paying for children's college

\begin{tabular}{|c|c|c|c|c|}
\hline & $\begin{array}{c}\text { Very } \\
\text { worried }\end{array}$ & $\begin{array}{c}\text { Moderately } \\
\text { worried }\end{array}$ & Not too worried & $\begin{array}{c}\text { Not worried } \\
\text { at all }\end{array}$ \\
\hline \multicolumn{5}{|l|}{ Gender } \\
\hline Women & $30.49 \%$ & $27.57 \%$ & $16.93 \%$ & $25.01 \%$ \\
\hline Men & $22.97 \%$ & $27.85 \%$ & $20.22 \%$ & $28.95 \%$ \\
\hline \multicolumn{5}{|l|}{ Race } \\
\hline White American & $26.28 \%$ & $28.67 \%$ & $18.60 \%$ & $26.45 \%$ \\
\hline African American & $32.40 \%$ & $22.43 \%$ & $16.85 \%$ & $28.32 \%$ \\
\hline Native American & $32.05 \%$ & $24.65 \%$ & $13.50 \%$ & $29.80 \%$ \\
\hline Asian American & $22.77 \%$ & $28.42 \%$ & $21.25 \%$ & $27.56 \%$ \\
\hline \multicolumn{5}{|l|}{ Hispanic } \\
\hline Hispanic & $38.80 \%$ & $26.72 \%$ & $14.95 \%$ & $19.53 \%$ \\
\hline Not Hispanic & $24.46 \%$ & $27.91 \%$ & $19.22 \%$ & $28.41 \%$ \\
\hline \multicolumn{5}{|l|}{ Insurance } \\
\hline Insurance $=$ Yes & $24.08 \%$ & $28.64 \%$ & $19.15 \%$ & $28.13 \%$ \\
\hline Insurance $=N o$ & $46.06 \%$ & $21.57 \%$ & $13.94 \%$ & $18.42 \%$ \\
\hline \multicolumn{5}{|l|}{ Citizen } \\
\hline Citizen $=$ Yes & $25.55 \%$ & $27.95 \%$ & $18.69 \%$ & $27.81 \%$ \\
\hline Citizen $=N o$ & $39.56 \%$ & $25.55 \%$ & $16.41 \%$ & $18.47 \%$ \\
\hline \multicolumn{5}{|l|}{ Education } \\
\hline Less than high school & $40.58 \%$ & $21.29 \%$ & $15.13 \%$ & $23.00 \%$ \\
\hline High school & $32.25 \%$ & $24.87 \%$ & $16.42 \%$ & $26.46 \%$ \\
\hline Some college & $30.14 \%$ & $27.34 \%$ & $16.78 \%$ & $25.74 \%$ \\
\hline College & $19.70 \%$ & $31.59 \%$ & $21.81 \%$ & $26.90 \%$ \\
\hline Post-college & $15.16 \%$ & $30.85 \%$ & $21.77 \%$ & $32.22 \%$ \\
\hline \multicolumn{5}{|l|}{ Age Groups } \\
\hline Adult & $28.06 \%$ & $28.58 \%$ & $18.63 \%$ & $24.73 \%$ \\
\hline Senior & $7.27 \%$ & $11.31 \%$ & $15.32 \%$ & $66.10 \%$ \\
\hline \multicolumn{5}{|l|}{ Marital Status } \\
\hline Single & $33.71 \%$ & $23.59 \%$ & $16.54 \%$ & $26.15 \%$ \\
\hline Married & $23.11 \%$ & $30.18 \%$ & $20.23 \%$ & $26.48 \%$ \\
\hline Partnership & $36.29 \%$ & $25.22 \%$ & $15.77 \%$ & $22.72 \%$ \\
\hline Separated/Divorced & $33.70 \%$ & $24.25 \%$ & $15.10 \%$ & $26.95 \%$ \\
\hline Widowed & $20.75 \%$ & $15.66 \%$ & $13.18 \%$ & $50.41 \%$ \\
\hline \multicolumn{5}{|l|}{ Smoking Status } \\
\hline Never & $24.59 \%$ & $28.90 \%$ & $20.05 \%$ & $26.46 \%$ \\
\hline Former & $24.62 \%$ & $28.17 \%$ & $16.68 \%$ & $30.53 \%$ \\
\hline Some-day & $31.95 \%$ & $26.60 \%$ & $16.77 \%$ & $24.68 \%$ \\
\hline Every-day & $41.24 \%$ & $21.32 \%$ & $13.81 \%$ & $23.63 \%$ \\
\hline Overall & $27.00 \%$ & $27.70 \%$ & $18.46 \%$ & $26.84 \%$ \\
\hline
\end{tabular}


Table 11. Worried about money for retirement

\begin{tabular}{|c|c|c|c|c|}
\hline & $\begin{array}{c}\text { Very } \\
\text { worried }\end{array}$ & $\begin{array}{c}\text { Moderately } \\
\text { worried }\end{array}$ & $\begin{array}{l}\text { Not too } \\
\text { worried }\end{array}$ & $\begin{array}{c}\text { Not } \\
\text { worried at } \\
\text { all }\end{array}$ \\
\hline \multicolumn{5}{|l|}{ Gender } \\
\hline Women & $24.64 \%$ & $31.40 \%$ & $23.89 \%$ & $20.08 \%$ \\
\hline Men & $18.98 \%$ & $31.50 \%$ & $26.69 \%$ & $22.82 \%$ \\
\hline \multicolumn{5}{|l|}{ Race } \\
\hline White American & $21.27 \%$ & $32.07 \%$ & $25.52 \%$ & $21.14 \%$ \\
\hline African American & $27.88 \%$ & $28.24 \%$ & $22.40 \%$ & $21.48 \%$ \\
\hline Native American & $28.80 \%$ & $28.94 \%$ & $20.98 \%$ & $21.27 \%$ \\
\hline Asian American & $16.52 \%$ & $31.64 \%$ & $28.26 \%$ & $23.58 \%$ \\
\hline \multicolumn{5}{|l|}{ Hispanic } \\
\hline Hispanic & $30.39 \%$ & $31.41 \%$ & $20.70 \%$ & $17.51 \%$ \\
\hline Not Hispanic & $20.20 \%$ & $31.46 \%$ & $26.16 \%$ & $22.18 \%$ \\
\hline \multicolumn{5}{|l|}{ Insurance } \\
\hline Insurance $=$ Yes & $18.98 \%$ & $32.21 \%$ & $26.40 \%$ & $22.41 \%$ \\
\hline Insurance $=N o$ & $41.76 \%$ & $26.48 \%$ & $17.29 \%$ & $14.46 \%$ \\
\hline \multicolumn{5}{|l|}{ Citizen } \\
\hline Citizen $=$ Yes & $21.09 \%$ & $31.58 \%$ & $25.51 \%$ & $21.82 \%$ \\
\hline Citizen $=$ No & $29.95 \%$ & $30.29 \%$ & $22.46 \%$ & $17.30 \%$ \\
\hline \multicolumn{5}{|l|}{ Education } \\
\hline Less than high school & $34.54 \%$ & $24.93 \%$ & $18.72 \%$ & $21.81 \%$ \\
\hline High school & $37.38 \%$ & $29.10 \%$ & $22.43 \%$ & $21.09 \%$ \\
\hline Some college & $25.53 \%$ & $32.35 \%$ & $23.26 \%$ & $18.86 \%$ \\
\hline College & $16.64 \%$ & $34.28 \%$ & $29.74 \%$ & $21.34 \%$ \\
\hline Post-college & $10.11 \%$ & $33.11 \%$ & $30.38 \%$ & $26.40 \%$ \\
\hline \multicolumn{5}{|l|}{ Age Groups } \\
\hline Adult & $22.80 \%$ & $32.16 \%$ & $25.29 \%$ & $19.75 \%$ \\
\hline Senior & $7.39 \%$ & $18.18 \%$ & $23.28 \%$ & $51.15 \%$ \\
\hline \multicolumn{5}{|l|}{ Marital Status } \\
\hline Single & $30.44 \%$ & $28.22 \%$ & $20.28 \%$ & $21.06 \%$ \\
\hline Married & $17.40 \%$ & $32.83 \%$ & $27.96 \%$ & $21.81 \%$ \\
\hline Partnership & $29.54 \%$ & $30.62 \%$ & $21.72 \%$ & $18.11 \%$ \\
\hline Separated/Divorced & $30.15 \%$ & $30.19 \%$ & $20.90 \%$ & $18.76 \%$ \\
\hline Widowed & $20.70 \%$ & $23.35 \%$ & $17.97 \%$ & $37.98 \%$ \\
\hline \multicolumn{5}{|l|}{ Smoking Status } \\
\hline Never & $18.66 \%$ & $32.32 \%$ & $27.22 \%$ & $21.80 \%$ \\
\hline Former & $21.78 \%$ & $31.69 \%$ & $24.15 \%$ & $22.38 \%$ \\
\hline Some-day & $27.34 \%$ & $32.52 \%$ & $20.52 \%$ & $19.62 \%$ \\
\hline Every-day & $37.49 \%$ & $26.40 \%$ & $18.10 \%$ & $18.02 \%$ \\
\hline Overall & $22.01 \%$ & $31.45 \%$ & $25.19 \%$ & $21.35 \%$ \\
\hline
\end{tabular}

